\title{
HUBUNGAN TINGKAT PENDIDIKAN IBU HAMIL TRIMESTER III DENGAN KETERATURAN KUNJUNGAN ANC
}

\section{Eka Sarofah Ningsih* \\ *Dosen Program Studi D III Kebidanan Universitas Islam Lamongan}

Pendidikan ibu hamil sangat penting dalam merespon perubahan setiap individu pada masa kehamilan. Didapatkan masih rendahnya cakupan K4 di BPS Dwenti. Bila semakin tinggi pendidikan seseorang, maka makin banyak pengetahuan yang dimiliki sehingga perlu menganalisa hubungan tingkat pendidikan ibu hamil trimester III dengan perilaku keteraturan kunjungan ANC. Hal ini sesuai dengan teori yang diungkapkan Soekidjo.

Penelitian ini menggunakan desain analitik observasional dengan pendekatan crosectional.Jumlah sampel dalam penelitian ini $32 \mathrm{ibu}$ hamil, sebagai sampel 30 responden. Dengan tehnik randem sampling. Variabel independen ini merupakan tingkat pendidikan ibu hamil Trimester III, dan variabel dependennya keteraturan kunjungan ANC Trimester III. Analisa penelitian dengan uji Coefisien kontigensi, instrumen penelitian ini dengan cheklist. Dengan tingkat kemagnaan $P<0,05$.

Hasil penelitian didapatkan menurut tingkat pendidikan diperoleh hasil tertinggi berpendidikan dasar sebanyak (60\%), dan menurut keteraturan ANC tertinggi tidak teratur ANC sebanyak (66,67\%), hubungan pendidikan dengan keteraturan ANC tertinggi berpendidikan dasar sebanyak (85,0\%). Hasil di uji dengan koefisien kontigensi dengan tingkat kemagnaan 0,000 dengan klasifikasi $\mathrm{p}<0,05$, artinya $\mathrm{H}_{0}$ ditolak.

Kesimpulan penelitian adalah ada hubungan antara tingkat pendidikan ibu hamil trimester III dengan keteraturan kunjungan ANC. Semakin tinggi pendidikan seseorang akan mempengaruhi perilaku seseorang untuk melakukan kunjungan maka pendidikan harus ditingkatkan pada seluruh masyarakat khusus ibu hamil.

\section{Kata kunci : Tingkat pendidikan, keteraturan kunjungan, ibu hamil}

\section{PENDAHULUAN}

Kehamilan merupakan salah satu proses yang akan terjadi bila aspek penting adanya ovum, spermatozoa, konsepsi dan nidasi (Dep kes, 1998 : 30). Kehamilan dimulai dari konsepsi sampai lahirnya janin lamanya 280 hari (40 minggu atau 9 bulan 7 hari) dihitung dari pertama haid terakhir (Sarwono,2002:89).

Manfaat secara khusus pengawasan antenatal mempunyai tujuan untuk mengenal sedini mungkin penyulit yang terdapat saat kehamilan, persalinan dan kala nifas. Selain itu untuk mengetahui berbagai resiko dan komplikasi hamil sehingga ibu hamil dapat diartikan untuk melakukan rujukan rumah sakit. Untuk evaluasi kedaan dan kemajuan inpartu dipergunakan partograf, menurut WHO sehingga pada saat mencapai garis waspada penderita sudah dapat dirujuk dari rumah sakit. Disamping itu, adapun manfaat dari perawatan antenatal yaitu memberikan nasehat dan petunjuk yang berkaitan dengan kehamilan, persalinan, kala nifas dan laktasi, aspek keluarga berencana (Manuaba, 1998:133).

Pendidikan merupakan serangkaian proses yang dilakukan secara 
sadar, berlangsung secara terus menerus, sistematis dan terarah, yang bertujuan untuk mendorong terjadinya perubahanperubahan pada setiap individu yang terlibat didalamnya. Dengan system pendidikan yang berjenjang diharapkan mampu meningkatkan pengetahuan individu melalui pola pikir tertentu (Gunarsa,2001:21). Semakin tinggi pendidikan seseorang, maka makin mudah menerima informasi sehingga makin banyak pula pengetahuan yang dimiliki. Sebaliknya pendidikan yang kurang akan lebih sulit dalam mempresepsi dan menghambat perkembangan sikap ibu terhadap nilai-nilai yang baru diperkenalkan, seperti pentingnya kunjungan ANC pada saat hamil .penatalaksanaan yang tepat dengan cara peyuluhan agar ibu lebih faham tentang pentingnya ANC pada ibu hamil terutama pada trimester III sehingga dapat merubah perilaku untuk melakukan ANC secara teratur (Nursalam dan Siti Pariani.2001:133).

Pada kehamilan trimester III sering muncul masalah psikologis antara lain kegelisahan, sehingga salah satu cara mengatasinya perlu memperkenalkan komplikasi akibat kehamilan dan pengobatnnya selama pengawasan Antenatal (Sarwono,2002 : 98 ). Salah satu usaha yang perlu di perhatikan pada ibu hamil trimester III dengan di lakukannya perawatan antenatal untuk memperkenalkan hal-hal yang terjadi selama trimester III baik perubahanperubahan fisik serta persiapan menjelang persalinan. Persiapan tersebut antara lain senam hamil dan pemenuhan nutrisi, tanda bahaya,tanda persalinan ,personal hyegien,perawatan payudara, istirahat, aktifitas dan seksualitas demi kesejahteraan ibu maupun janin.

Berdasarkan keputusan menteri kesehatan RI No.1475/Menkes/SK/X/2003 tentang standart pelayanan kesehatan minimal dibidang kesehatan target kunjungan baru (K1) adalah 95\% dan kunjungan yang keempat (K4) adalah 95\%. Pencapaian
Target diKabupaten lamongan pada tahun 2010 , K1 adalah 94,4 \% dan K4 adalah 97,01\%. Pada data awal di BPS Dwenti pencapaian target cakupan tahun 2010 telah memperoleh $\mathrm{K} 180,74 \%$ dan $\mathrm{K} 4$ adalah 68,23\%. Berdasarkan hasil prosentase diatas dapat diketahui masih rendahnya kunjungan awal (k1) dan kunjungan keempat (K4) padahal disetiap daerah terdapat kebijakan teknis tersendiri yang ditempuh dalam mengupayakan kesehatan ibu dan anak. Kebijakan teknis yang dilakukan melalui program $\mathrm{P} 4 \mathrm{~K}$ (perencanaan persalinan dan pencegahan komplikasi), kemitraan bidan dan dukun, program Jamkesmas dan Jamkesda serta Jampersal (di Lamongan semua pelayanan rawat jalan di puskesmas gratis), dan melakukan kunjungan di rumah ibu hamil, ibu nifas yang kesulitan datang (Depkes, 2007).

Proses kehamilan terbagi menjadi tiga trimester, yang lebih menekankan pada realitas praktis terhadap harapan orang tua. Kejadian yang sering terjadi pada trimester ini berbagai khayalan dari lamunan yang datang mengenai bayi dan orang tua yang lemas, yang berfokus pada kemungkinan cacat dalam kemampuan mental dan fisik anaknya. ( dikutip dan Bobak 2002 : 104 ). Untuk memantau perubahan - perubahan fisik dan tumbuh kembang janin diperlukan pelayanan antenatal yang merupakan cara penting untuk memonitor dan mendukung kesehatan ibu hamil normal dan mendeteksi ibu dengan kehamilan secara dini sehingga dapat di perhitungkan dan dipersiapkan langkah-langkah dalam pertolongan persalinannya. Diketahui bahwa janin dalam rahim ibunya merupakan suatu kesatuan yang saling mempengaruhi sehingga kesehatan ibu yang optimal akan meningkatkan kesehatan, pertumbuhan dan perkembangan janin. Ibu hamil di anjurkan untuk melakukan pengawasan antenatal, pada Trimester III minimal dua kali (Manuaba, 1998:128). 
Pelayanan kesehatan suatu Negara dapat dilihat dari rendahnya angka kematian ibu yang lebih mencerminkan kesanggupan suatu Negara untuk memberikan pelayanan kesehatan (Manuaba, 1998 :8). Salah satunya hasil penelitian setiap tahun ada sekitar 200.000 juta ibu hamil di negara berkembang 500.000 diantaranya akan meninggal karena penyebab yang berhubungan dengan kehamilan (Modul Bidan di Masyarakat, 2001:37).

Upaya untuk meningkatkan keteraturan ANC agar dapat sesuai standar maka seorang bidan jika menangani pasien harus memperhatikan pendidikan ibu, meningkatkan peran keluarga, meningkatkan motifasi ibu untuk melakukan kunjungan ANC secara teratur supaya dapat mendeteksi adanya penyakit secara dini.

\section{TUJUAN PENELITIAN}

Memperoleh $\begin{gathered}\text { gambaran dan } \\ \text { mendapatkan pemahaman }\end{gathered}$ serta
kemampuan untuk untuk nyata tentang
teori dan praktek lapangan untuk
mengembangkan pola pikir dan dapat
melaksanakan asuhan kebidanan sesuai
standar dengan menggunakan
pendokumentasian manajemen kebidanan
(SOAP) pada hubungan tingkat pendidikan
ibu hamil trismester III
keteraturan kunjungan Ante Natal Care di
BPS Dwenti K.R,Amd.Keb bulan Januari
sampai Mei tahun 2011

\section{METODE PENELITIAN}

Dalam pemberian asuhan kebidanan kehidupan pada klien bidan menggunakan metode pendekatan pemecahan masalah dengan difokuskan pada suatu proses sistematis dan analisis. Pemberian asuhan kebidanan tersebut, penulis menggunakan untuk langkah penelitian ini disajikan dalam 2 bentuk yaitu data umum dan data khusus. Data umum berupa karakteristik responden berdasarkan umur, pekerjaan dan paritas ibu hamil, sedangkan data khusus yang disajikan berupa : pendidikan ibu hamil dengan keteraturan kunjungan ANC.

\section{HASIL DAN PEMBAHASAN}

\section{Pendidikan}

Dalam pembahasan ini peneliti akan menjelaskan lebih lanjut tentang hubungan tingkat pendidikan ibu hamil trimester III dengan keteraturan kunjungan ANC di BPS Dwenti, K.R, Amd.Keb Desa Sumberejo Kabupaten Lamongan 2011.

Berdasarkan data diatas sebagian besar ibu yang memiliki tingkat pendidikan dasar sebanyak 18 orang (60\%), yang berpendidikan menengah 9 orang (30\%), sedangkan yang berpendidikan tinggi sebanyak 3 orang (10 $\%$ ). Hal ini membuktikan bahwa semakin tinggi pendidikan seseorang maka semakin mudah dalam menerima informasi sehingga semakin banyak pula pengetahuan yang dimiliki, sebaliknya pendidikan yang kurang menghambat sikap seseorang terhadap niai-nilai yang diperlukan.

Semakin tinggi pendidikan seseorang, maka makin mudah menerima informasi sehingga makin banyak pula pengetahuan yang dimiliki. Sebaliknya pendidikan yang kurang akan lebih sulit dalam mempresepsi dan menghambat perkembangan sikap ibu terhadap nilainilai yang baru diperkenalkan.

\section{Keteraturan kunjungan ANC}

Pada umur ibu hamil ini yang berusia <20 sampai >30 tahun hampir setengahnya tidak teratur dalam melakukan kunjungan ANC dan sebaliknya teratur dalam melakukan kunjungan ANC. Responden berdasarkan keteraturan kunjungan yang tertinggi sebanyak 20 orang $(66,67 \%)$. Sedangkan terendah sebanyak 10 orang $(33,33 \%)$.

Kehamilan adalah dimulai dari konsepsi sampai lahirnya janin lamanya 280 hari (40 minggu atau 9 bulan 7 hari) dihitung dari pertama haid terakhir 
(Sarwono,2002:89). Kehamilan dibagi menjadi triwulan, yaitu : Kehamilan triwulan pertama umur kehamilan : 0-16 minggu, Kehamilan triwulan kedua umur kehamilan : 17-28 minggu dan Kehamilan triwulan ketiga umur kehamilan : 29-42 minggu.

\section{Pendidikan dengan keteraturan} kunjungan ANC

Berdasarkan data diatas data responden tingkat pendidikan rendah dengan keteraturan kunjungan ANC yang tertinggi sebanyak 17 orang $(85,0 \%)$. Sedangkan berdasarkan pendidikan dasar yang teratur hanya 1 orang $(10 \%)$.

pada Trimester I minimal kunjungan satu kali, pada trimester II minimal kunjungan dua kali dan pa trimester III minimal dua kali. Kunjungan ulang yaitu kunjungan yang dilakukan wanita setelah melakukan pemeriksaan antenatal pertama. Sebaliknya pendidikan yang kurang akan lebih sulit dalam mempresepsi dan menghambat perkembangan sikap ibu terhadap nilai-nilai yang baru diperkenalkan, seperti pentingnya kunjungan ANC pada saat hamil .penatalaksanaan yang tepat dengan cara peyuluhan agar ibu lebih faham tentang pentingnya ANC pada ibu hamil terutama pada trimester III sehingga dapat merubah perilaku untuk melakukan ANC secara teratur

\section{KESIMPULAN DAN SARAN}

\section{Kesimpulan}

Dari hasil penelitian dan pembahasan Bab 6 dapat disimpulkan bahwa hubungan tingkat pendidikan ibu hamil Trimester III dengan keteraturan kunjungan ANC yang dilaksanakan pada bulan Januari sampai Mei 2011 degan jumlah 30 responden di BPS Dwenti K,R. Amd.Keb Desa Sumberejo Kabupaten Lamongan dapat disimpulkan bahwa tingkat pendidikan ibu hamil Trimester III dengan keteraturan kunjungan ANC yang berpendidikan dasar sebanyak 18 orang
(60\%), yang berpendidikan menengah 9 orang $(30 \%)$, sedangkan yang ber pendidikan tinggi sebanyak 3 orang (10 $\%)$.

2. Saran

2.1. Bagi BPS

Dapat meningkatkan pengetahuan dan keterampilan dan untuk memberikan pelayanan ANC sesuai dengan standart pelayanan.

2.2. Bagi Peneliti

Peneliti hendaknya dapat mengembangkan penelitian ini dengan menggunakan metodologi penelitian yang baik dengan memperluas sampel dan menggunakan instrumen yang telah diujikan dan lebih selektif agar hasil dapat lebih bermanfat untuk daerah luas.

2.3. Bagi Responden atau Masyarakat

Responden yang tidak teratur dalam melakukan kunjungan ANC perlu ditingkatkan dengan memberikan motivasi informasi serta penyuluhan, meningkatkan stimulasi melalui media yang ada misalnya dengan tulisan atau poster yang berkaitan dengan keteraturan kunjungan ANC bagi ibu hamil.

2.4. Bagi Institusi Pendidikan

Pendidik atau pengajar atau dalam hal ini dosen diharapkan dapat memberikan bimbingan secara intensif terutama pada materi asuhan kebidanan 1 atau ANC, mengingat tugas bidan sebagai pemberi pelayanan langsung kepada masyarakat.

\section{DAFTAR PUSTAKA}

Alimul Hidayat A. 2006. Pengantar Kebutuhan Dasar Manusia: Aplikasi dan Proses Keperawatan. Jakarta: Salemba Medika

Alimul Hidayat A. 2003. Riset keperawatan dan teknik penulisan ilmiah. Jakarta: Salemba Medika

Arikunto, Suharsimi. 1998. Prosedur Penelitian Suatu Pendekatan Praktek. Jakarta: Rineka Cipta. 
Azwar S. 2003, Sikap Manusia, Teori dan Pengukurannya. Yogyakarta: Pustaka Pelajar.

Bobak. 2005. Buku Ajar Keperawatan Maternitas. Jakarta: EGC.

Depkes. RI.1998.Perawatan Antenatal. Jakarta Depkes

Farrses. H. 2001. Perawatan Maternitas. Jakarta : Bhratara

Manuaba, IGB. 1998. Ilmu Kebidanan, Penyakit Kandungan dan KB Untuk Pendidikan Bidan. Jakarta: EGC.

Notoatmojo, Soekidjo, 2003. Ilmu Kesehatan Masyarakat. Cetakan 1. EGC: Jakarta.

Notoatmojo, Soekidjo, 2005. Metodologi Penelitian Kesehatan. Cetakan ketiga. PT. Rineka Cipta: Jakarta.

Nursalam dan Siti Pariani. 2001. Pendidikan Praktis Metodologi Riset Keperawatan. Jakarta: CV. Infomedia.

Nursalam. 2003. Konsep dan Penerapan Metodelogi Penelitian Ilmu Keperawatan. Salemba Medika: Jakarta.

Prawirohardjo, Sarwono. 2005. Ilmu Bedah Kebidanan. Cetakan 6. YBP-SP: Jakarta.

Prawirohardjo, Sarwono. 2006. Buku Acuan Nasional Pelayanan Kesehatan Maternal dan Neonatal. Cetakan 6. YBP-SP: Jakarta.

Rustam, M.1998. Sinopsis Obstetri, Jilid 1. Jakarta : EGC

Stoppard, M. 2006. Pelayanan Mempersiapkan Kehamilan Dan Kelahiran. Yogyakarta : Pustaka Pelajar

UNPAD. 1999. Senam Hamil. Bandung : Elstar Offset 